\title{
Hegemony Without Tears: Definitions and uses of hegemony from Gramsci onwards
}

\author{
Connor Thompson
}

Antonio Gramsci has proved to be one of the most influential Marxist writers since Marx himself, and has had a profound impact on academic writing since his Prison Notebooks first became widely available. However, his most famous conceptual contribution to academic discourse - his definition of hegemony - has led to a variety of different interpretations and uses in the historical field in particular, not all of which are necessarily in agreement with one another. The concepts that feed into Gramsci's definition of hegemony have similarly been reinterpreted and reconfigured over their years of employment by scholarship. This paper takes several "case studies" of prominent Gramscian academics, and by comparing their uses of hegemony and other ideas of Gramsci's, illuminates areas of agreement and disagreement between scholars as concerns the concept of hegemony.

Gramsci's theory of history proves pervasive, in spite of (or, perhaps, because of) his nebulous definition of hegemony. It was enough to read his Prison Notebooks, written between 1929 and 1935 while Gramsci was imprisoned under Mussolini, and take his insinuations about the nature of hegemony to craft a theory around this concept. Unlike Marxist theory - where much of its development was done by its originator, and where we have firm definitions about different "Marxisms" based on how they differ from the "original" theory - those who use Gramsci essentially can only have a foggy understanding as to how they differ from the original theory of hegemony. At a minimum, this self-consciousness of the individual scholar's differentiating qualities from Gramsci's own "hegemony" are quite less apparent than most other historical methodologies. As such, this essay will analyze two things about those scholars we might deem Gramscians: firstly, their understanding and application of hegemony, and secondly, their understanding of how they themselves relate to Gramsci. This approach will allow us an insight into how the scholar interacts with Gramsci, and how they themselves understand their use of him: are they consciously modifying his theory, or are they positioning themselves to appear to be using an "authentic" understanding of Gramsci's hegemony?

I intend to pursue several different scholars who consciously use Gramsci in their method. Two examples will be histories, and two will be scholars writing about Gramsci and thus trying to define both hegemony and the way Gramsci thinks. I will analyze the historians Jonathon 
Glassman in his book Feasts and Riots, and Eugene Genovese's From Rebellion to Revolution. I will then look at two different scholars - the former, a cultural theorist/sociologist, the latter, a highly prominent Gramsci scholar and historian of Italy. We will look here at critical works on Gramsci written by these scholars: Stuart Hall's "Gramsci's Relevance for the study of Race and Ethnicity", and John Cammett's Antonio Gramsci and the Origins of Italian Communism. Having done this, I will see what areas of agreement exist between these four scholars, and where their opinions diverge.

Genovese considered Gramsci the greatest Marxist writer of the $20^{\text {th }}$ century, and the influence of his concept of hegemony on Genovese's writing - specifically about the antebellum South - "is not hard to see." "His main historical focus was on American slavery, and Genovese enjoyed a reputation as being a "“good" Marxist" amongst academics in his field. ${ }^{2}$ In his book From Rebellion to Revolution, Genovese does not offer an explicit assessment of Gramsci's concepts: for that, we have to turn to the work that preceded it - that is, Roll Jordan Roll. This book is probably Genovese's most famous, and is a location at which he very directly discusses Gramsci. Genovese claims that hegemony, as an idea, "implies class antagonisms; but it also implies, for a given historical epoch, the ability of a particular class to contain those antagonisms on a terrain in which its legitimacy is not dangerously questioned." ${ }^{3}$ This, for the purpose of Genovese's study, makes sense in terms of where he focuses as regards a definition of hegemony, and is something we will see Genovese use as a framework for From Rebellion to Revolution. Genovese also explicitly acknowledges his use of Gramsci's "incisive thesis on popular consciousness", quoting Gramsci at length in his explanation of the two theoretical consciousnesses - or the one contradictory consciousness. ${ }^{4}$ As such, Genovese gives off the affectation of letting Gramsci speak for himself, preferring instead to simply act on his understanding of Gramsci rather than offering an explanation of how he sees Gramsci.

A sizeable portion of the preface to From Rebellion to Revolution focuses on establishing a context for the slave society, which grew within "the prevailing European mode of production." Reading solely the preface, one might assume Genovese's work to thereafter be a rather traditional Marxist history, focused on class relationships and how the control over the means of production (the slaves) influenced the slave revolts. This presumption is quickly dispelled. In establishing the nature of slave revolts in the Americas, Genovese assumes that they occurred

\footnotetext{
${ }^{1}$ Richard King, "Marxism and the Slave South" in American Quarterly 29: 1 (1977), 118.

${ }^{2}$ King, 119.

${ }^{3}$ Eugene D. Genovese, Roll, Jordan, Roll: The World the Slaves Made (New York: Pantheon Books. 1974), 25-26.

${ }^{4}$ Genovese, Roll, 147-148.

${ }^{5}$ Eugene D. Genovese, From Rebellion to Revolution: Afro-American Slave Revolts in the Making of the Modern World (Baton Rouge: Louisiana State University Press. 1979), xvi.
} 
within the still "bourgeois movement" for principles of "freedom, equality, and democracy" which also acted as a precursor to the resistance against capitalism as a system. ${ }^{6}$ This is important to note because, even though these are clearly the base assumptions that From Rebellion operates on, the actual economic conditions become less and less the focus, as opposed to social and cultural relationships, throughout most of the book. Genovese makes the point that the white slaveholders, and their hegemonic power, confined all struggles and class divisions "to issues other than that of property." In short, the slaveholders managed to keep sharpening class divisions from challenging the holding of people as property - perfectly in line with the aforementioned postulation we see in Roll, Jordan, Roll. Moreover, with the growth in Creole to African-born slaves in the South, "the cultural distance between masters and slaves narrowed, the foundations of a regional paternalism grew progressively stronger." United States at least, a hegemonic power over the slaves that was absent in some of the other slave societies Genovese elaborates on; both of these things allowed white hegemony to persist longer as a result. By taking into account socio-cultural aspects of the slave-master relationship, without then attributing this relationship to a purely super-structural explanation, we can see Genovese using Gramscian tools of historical analysis, and a Gramscian resistance to the economism of many Marxist intellectuals. Throughout the book, Genovese takes into account many aspects of the tensions surrounding slave revolts in the Americas that a traditional Marxist interpretation would be unlikely to encounter, in particular, in the areas of culture.

It should be emphasized that these descriptions are all still framed within the realm of sheer force of arms, and who has the arms is of course a matter of class. That being said, Genovese is quite comfortable employing the term "hegemony", which seems to take a rather "traditional" and firm meaning for him - that is, a cultural/ideological power that is agreed upon by multiple classes (the whites, and some elements of the Creoles, maroons, black slaves, etc. in From Rebellion to Revolution), and which is underpinned, rather than solely dependent on, coercive force. In his discussion of white hegemony, he takes the alignment of interests, across classes, of whites - all of whom benefited from the slave system - as a state of hegemonic power. ${ }^{9}$ To take another example, in his discussion about the "literate Muslim leaders in Bahia", he describes these leaders as forging alliances between both free and slave urban blacks by virtue of their syncretism - i.e. the ability to assimilate Muslim religion with "the traditional African and

\footnotetext{
${ }^{6}$ Genovese, From Rebellion, 1-2.

${ }^{7}$ Genovese, From Rebellion, 26-27.

${ }^{8}$ Genovese, From Rebellion, 5.

${ }^{9}$ Genovese, From Rebellion, 27. One could also look at his description of Indian-black ambivalence on page 71 as a description of white hegemony. This state of hegemony between the white classes breaks down, in Saint-Domingue at least, on page 86 .
} 
emerging Afro-American religions." This "ideological hegemony" allowed them a leadership role in "a firm and disciplined revolutionary effort."

Reading Glassman against Genovese, it seems clear that Glassman is not in the Marxist mainstream in the way that Genovese was: these two histories read very differently. In Glassman's introduction, he engages in a fairly lengthy dissertation on the theorists he employs in writing about the Swahili coast during the early German colonization process. Glassman, as he employs Gramsci, focuses on the idea of "popular consciousness" as a means of framing how he perceives the plebeian crowds, and their interactions with other classes. In Glassman's view, Gramsci saw ideology not as being a cohesive whole, but as cogent discourse. Language and ideology prove to be the locations where people gain knowledge of their class, their subjugation, and so on. Glassman also makes clear that he assesses Gramsci's hegemonic ideology not to mean an ideology produced by "one particular class, nor did he [Gramsci] believe it to give unambiguous expression to the interests of the dominant class." produced by the lower classes may appear inconsistent, and are "usually expressed in language marked by hegemonic ideologies," but are nonetheless powerful tools of mobilizing the lower classes. ${ }^{12}$ He positions his conceptualization of popular consciousness as a hegemonic ideology that comes from many different philosophies and ideas produced by disparate times and places, which is then employed by many different classes. It is noted that this hegemonic ideology conflicts with the everyday circumstances under which the plebeian lives, creating a "contradictory consciousness" that must be grappled with, but which would be erroneous to read as "the absolute domination of the thought of the subordinate population."

While neither Genovese nor Glassman treat the economic conditions as their main focus in their respective books, they both introduce them, and comment on them, but then let them - for the most part - smoulder in the background of the primarily cultural/ideological tensions. They also do not treat (what Marx would call) the bourgeois solely as oppressors, but instead, give a great deal of agency to the lower classes. For Genovese, the maroon communities, for example, made conscious decisions, creating cultures that challenged both white hegemony and allegiance with slaves, and "generally had a destructive impact on slavery". In Glassman, we also see a similarly large allocation of time to the influence of all classes on the composition of his history.

\footnotetext{
${ }^{10}$ Genovese, From Rebellion, 29.

${ }^{11}$ Jonathon Glassman, Feasts and Riots: Revelry, Rebellion, and Popular Consciousness on the Swahili Coast, 1856-1888 (Portsmouth: Heinemann. 2003), 18.

${ }^{12}$ Glassman, 19.

${ }^{13}$ Ibid.

${ }^{14}$ Genovese, From Rebellion, 55.
} 
Glassman's hegemony is probably quite a bit more pliable than Genovese's. What I mean is this: Genovese seems to use the term hegemony primarily to refer to the dominant culture, and its implications as a cause for struggle and resistance in Afro-American slave revolts. Glassman, however, seems to use the idea of hegemony to refer to an ideological/cultural balancing act that tips many different ways over the course of his historical narrative. Glassman is dealing with a wide variety of different peoples: indeed, the Swahili coast was alive in contradiction and cultural incongruities. He goes to great lengths to explain the economic conditions, as well as how economics tie into culture, devoting the first three chapters to "discuss how urban markets came to play an important part in the lives of humble people on the coast and in its hinterland." In the long descriptions of the caravan trade, ${ }^{16}$ the "dominant view of the masters" and the aspirations of the slaves, ${ }^{17}$ the struggle of the Sultanate to establish authority on the mainland, the increasing debt to Indian creditors, etc.; we see Glassman placing great weight on a wide variety of socio-cultural aspects of the popular consciousness that characterized the Swahili coast. Glassman ties this heavily to economics on multiple occasions. To take one example that is (for me) rather telling:

"Most townspeople perceived community authority in terms rooted in the values of village society, values at odds with many of those by which the Omani state elites and their allies justified their power. Whereas the state was imposed from above by a largely foreign administrative and military elite, the Shirazi patricians derived their authority from the participatory rituals of everyday life. Omani hegemony was reinforced by ideologies of merchant capital and commodity exchange, in which power accrued to whoever dominated the production and marketing of exchange values." ${ }^{18}$

We see, above, the word "hegemony" seems to function as an indication of primarily culture and ideology that permeates into, and is reflected by, multiple aspects of day-to-day life. The values of the townspeople are contrasted with the values of the Omani state, and Glassman notes that the hegemonic power of the state (which is evidently both values and coercive force, in this quote) is reinforced by market ideologies, which cannot be entirely ideologies produced by the state because such exchange occurred outside the state. We see the center of hegemonic power shifting in this account, as the Shirazi patricianate became increasingly indebted to Indian

\footnotetext{
${ }^{15}$ Glassman, 36.

${ }^{16}$ In particular, Glassman 68-78. One thing that, it seems to me, clearly separates Glassman as a Gramscian is on page 69 where he describes the religious/cultural diffusion along with the economic conditions of the caravan trade of the Pangani.

${ }^{17}$ Glassman, 79-80.

${ }^{18}$ Glassman, 173.
} 
creditors - who thereby gained more economic power. At the same time, the Omani Sultanate attempted to assert its power, and the Germans attempted to consolidate administrative power. As such, Glassman is placing a good deal of "weight" onto multiple ideologies, which all feed into the hegemonic balancing act that shifts in a variety of directions by the end of Feasts and Riots. The understanding of hegemonic power is handled by Glassman in a way that accounts for many, many more cultural/social/ideological factors, in that the emphasis on popular consciousness and its role in hegemonic authority is quite clearly at the forefront, allowing for the expression of shifts and changes in where exactly the hegemonic power lies - and appears to lie, depending on the perspective of the socio-cultural group. Genovese takes into account cultural, social, and ideological factors of all classes, but in the final analysis, hegemony becomes an emphasis on how the ruling white class directs discourse, deflecting away from threats to the slave regime. Popular consciousness' role in hegemonic authority becomes ancillary to this main argument.

We will draw further contrast between Genovese and Glassman at the end of the paper. To turn, now, to the two scholars who are defining Gramsci's hegemony. Stuart Hall, in his essay on Gramsci's relevance to the study of racism, frames Gramsci's theory in this way: the application of Gramscian theorizing is quite heavily limited, and operates within a historical materialist framework that, while clearly Marxist, was not in any way strict. Gramsci, Hall says, understood that a Marxist framework had to be "constantly developed theoretically", and reconstituted for new historical situations. ${ }^{19}$ In other words, Stuart Hall seems to think of Gramsci as a Marxist who was heavily open to innovations, and who, throughout this career, heavily innovated Marxist thinking himself.

Hall offers a fairly clear definition of hegemony. Interestingly, and unlike every other scholar I reviewed in this paper, Hall refers to a "moment" of hegemony. The creation of alliances between classes and the creation of consent to rule of one particular social group is treated as culminating in a "moment" that "transcends the corporate limits of purely economic solidarity, encompasses the interests of other subordinate groups," and diffuses through the society, manifesting in "intellectual and moral as well as economic and political unity." "This is qualified by the understanding of Gramsci's hegemony as being a "very particular, historically specific, and temporary "moment" in the life of a society." "What is interesting, here, is that unlike Genovese and Glassman's use of this concept, the sort of unity Hall is referring to would, indeed, be highly uncommon throughout history. He also places a greater deal of historical specificity and particularity on the concept of hegemony than the other theorists we have looked at so far.

\footnotetext{
${ }^{19}$ Stuart Hall, "Gramsci's Relevance for the Study of Race and Ethnicity" in Journal of Communications Inquiry 10: 5 (1986), 5.

${ }^{20}$ Hall, 14.

${ }^{21}$ Hall, 15.
} 
Hall also notes Gramsci's hegemony as being defined by historical blocs, rather than a ruling class acting as leader. Hall understands this concept of historical blocs as encompassing, perhaps, "only one fraction of the dominant economic class", with various aspects of the lower classes being some of the bloc's most important and historically influential aspects. ${ }^{22}$ But, the concept of hegemony was enriched, over the course of Gramsci's career, by his concept of the state. The state is treated as more than "simply an administrative and coercive apparatus", but instead as a profound socio-cultural actor, in that it is an "educative and formative" operator in society. Moreover, it "is the point from which hegemony over society as a whole is ultimately exercised (though it is not the only place where hegemony is constructed). ${ }^{23}$ This enriched definition of the state imbues hegemony with a more powerful analytical ability, and taking the example of the post-colonial state, Hall asserts that such a definition dispels the illusion of the "often assumed... simple, dominative or instrumental model of state power. ${ }^{24}$ The allowance of culture a large deal of power in its own right, and the various (and often contradictory) understandings of "common sense" are also important to Hall's understanding of hegemony, as they "constitute a crucial site for the construction of a popular hegemony." ${ }^{25}$ It is worth noting here as well that, overall, Hall presents his analysis of Gramsci as quite authoritative, and particularly so his understanding of hegemony. This apparently objective definition of hegemony and Gramscian theory is then justified in its application to scholarly writing on racism, in particular.

We will now look at a man who could likely be called the foremost American historian of Antontio Gramsci: John Cammett, and his book Antonio Gramsci and the Origins of Italian Communism. Cammett dedicates a subchapter of the book to "the concept of Hegemony." A rather succinct definition of the concept is offered: "In its general sense, hegemony refers to the "spontaneous" loyalty that any dominant social group obtains from the masses by virtue of its social and intellectual prestige, and its supposedly superior function in the world of production." ${ }^{26}$ Cammett also points out that hegemony meant to Gramsci, in a more limited sense, the "projected alliances of a predominant working class with other "subaltern" but "progressive" social elements, especially the peasantry, parts of the petty bourgeoisie, and the intelligentsia."," Cammett notes that, underpinning Gramsci's understanding of the concept of hegemony, is the assumption that the class trying to achieve hegemonic power within the State must not only

\footnotetext{
${ }^{22}$ Ibid.

${ }^{23}$ Hall, 18.

${ }^{24}$ Hall, 19.

${ }^{25}$ Hall, 26.

${ }^{26}$ John Cammett, Antonio Gramsci and the Origins of Italian Communism (Stanford: Stanford University Press. 1967), 204.

${ }^{27}$ Ibid.
} 
obtain political control, but cultural and ethical control. ${ }^{28}$ Cammett emphasizes that, for him, Gramsci saw hegemony as "rule by consent.","

This definition of hegemony places it in a much more narrow context in that it frames Gramsci as writing not of a theory of history, but more strictly, a theory of Communist Revolution. It is the so-called "cultural front" that needs to be won by the communists in order to obtain hegemonic influence, and this is what Gramsci was primarily addressing in his writings about this concept. Cammett seems to understand Gramsci as being deeply concerned, first and foremost, with what was happening in Italy, and was hesitant to speak at the level of the theoretical. In his introduction, Cammett defines his discussion of the prison writings as being focused primarily on two things: Gramsci's ideas about the political party, and the role of Italian intellectuals. He dismisses the other writing in the Prison Notebooks as being "interesting, and some of it profound; but it is on these two topics above all that Gramsci lavished the hard-won wisdom of his political career." that it is important "not to mistake the level of application at which Gramsci's concepts operate", but often seems - to this reader, at least - to write of Gramsci as though he were, indeed, writing quite often at the level of the theoretical. ${ }^{31}$ This contradiction in Hall is probably what is most interesting in reading him against Cammett, in that it reveals that Cammett's understanding of Gramsci as a writer who understood his own work as quite contingent and limited remains consistent. Within Hall, his own understanding of Gramscian theory seems to display some inconsistencies. ${ }^{32}$ I will refrain from digressing on this further, as my main purpose here is comparative as opposed to critical, but it is worth noting as an evident contradiction.

These four scholars each, clearly, have room for agreement as regards understanding the concept of hegemony and Gramsci more generally. From what I am able to obtain from their writings, I

\footnotetext{
${ }^{28}$ Cammett, 205.

29 Ibid.

${ }^{30}$ Cammett, xiv.

${ }^{31}$ Hall, 5.

${ }^{32}$ One example I will mention: On Gramsci's challenge to the economism of other Marxists: "In short, until one has shown how "objective economic crises" actually develop, via the changing relations in the balance of social force, into crises in the state and society, and germinate in the form of ethical-political struggles and formed political ideologies, influencing the conception of the world of the masses, one has not conducted a proper kind of analysis, rooted in the decisive and irreversible "passage" between structure and superstructure." Hall, 11. This sort of engagement of Marxist theory on such a broad level is evidence of Gramsci's writing transcending merely the provincial concerns within Italy and entering into a much larger arena of conceptual debate. Hall himself elaborates on Gramsci's various theoretical/intellectual developments and conceptualizations of history for more than a third of the article, all of which engage such enormous concepts such as the state, historical transitions, class alliances, and so on. I think it something of a challenge to reconcile the statement at the beginning of the article that Gramsci was purely "a political intellectual and social activist of the Italian political scene" (5) with Hall's focusing on Gramsci's theoretical/conceptual writing in this way.
} 
would list these areas of agreement as follows. Firstly, hegemony is clearly more than just coercive force, but includes a concept of cultural power that accounts for the interests of several different classes/socio-cultural groups. This is very clear in each of the readings, and is the basest definition of hegemony the reader will encounter. Secondly, hegemonic power is much more elusive than the traditional conception of power - which takes as its basis, coercive force - and is a useful concept for analyzing how a state of hegemony breaks down. In both Glassman and Genovese, we are analyzing the dissolution (or, one could argue, the shifting) of hegemonic power. Hall is advancing what he seems to see as an "objective" definition of Gramsci's theory, which he is then asserting to have a strong utility for a particular area of study. He is trying to convince us that, on this objective/fair-minded definition of hegemony, it has great utility for very specific areas of scholarly study. Cammett is framing Gramsci's hegemony in a very strong Marxist revolutionary understanding of history, where the transition is from one state of socio-cultural (as well as coercive) control to a new state. Cammett understands and defines Gramsci's hegemony in this way, and indeed, he is looking, in his book, at Gramsci's career as an attempted revolutionary. All of these understandings offer a clear indication that Gramsci emphasized the cultural sphere in his writing on hegemonic power, and that it is rooted in the elusive world of control over discourse and ideology.

Three of these readings deal in a significant way with the concept of popular consciousness. The control of the hegemonic ruler(s) over language, and the discourse in which all other classes operate, is probably one of the most profound ideas advanced by Gramsci, and as Glassman points out, Gramsci exhibited "a keen interest in linguistics, and recognized that language can convey and reproduce inherent perceptions of the world". ${ }^{33}$ The understanding of popular consciousness as being a production of philosophies/ideologies from many different times feeding into a particular period as fragments, thereby producing the "common sense" of a particular historical context, is something that is seized upon quite heavily by Genovese, Hall and Glassman, but does not enter - certainly - into Cammett's immediate definition of hegemony. This only enters into the rest of his book in a limited way, and in fact, Cammett, at least at one point, outright contradicts Glassman's assessment of how Gramsci perceived the consciousness of the subaltern classes - Cammett claims that these lower classes "will characteristically express themselves "spontaneously," since they have no effective leadership or class consciousness." "34 By contrast, Glassman asserts that "Gramsci's concepts would be of little use in our search for an understanding of the consciousness of peasant and plebeian resistance if they implied that the subordinate population is locked into acquiescence or inaction," which of

\footnotetext{
${ }^{33}$ Glassman, 17.

${ }^{34}$ Cammett, 198.
} 
course, Glassman asserts is not the case. ${ }^{35}$ Glassman understands Gramsci as "scorn[ing] the idea... that peasant rebellion was inherently reactionary". "This distinction between the two points of view is important in itself, but for a definition of hegemony, understanding the concept of how the hegemonic ideology is distributed through society is, of course, vital in actual analysis of the historical events in which one is framing a hegemonic understanding. Genovese appears to use this idea to considerable effect in From Rebellion to Revolution, noting that Afro-American slave revolts framed their demands, at several times, in the language of European revolutions. ${ }^{37}$ Genovese, at multiple points, devotes time to the exploration of the religions of the slaves - for example, the aforementioned syncretism of Muslim with "traditional African and emerging Afro-American religions" among Bahia slaves. ${ }^{38}$ We could also look at Genovese's analysis of the blending of slave folk religion "into Baptist and Methodist beliefs and practices", producing a "vigorous doctrine of spiritual equality, which the slaves translated into political terms." Genovese, again, seems to operate quite strictly on the understanding of popular consciousness he presents in Roll, Jordan, Roll, which he relates primarily through Gramsci's own words, as opposed to offering us an explanation of his own understanding of it.

Each author is advancing what is presented as an objective definition of hegemony and Gramsci's theory. This is one of the most interesting aspects of analyzing Gramscian historians, or historians offering an elucidation on Gramsci: despite there being very obvious and firm areas of agreement in understanding what exactly Gramsci's understanding was of his own theory, there are several other aspects of each understanding of Gramsci - even in the small sample this paper covers - which are presented as objective, and yet, disagree with each other. Part of the problem in the first place is that Gramsci was forced, due to his being a Marxist in a fascist prison, to censor himself. Often, Gramsci's notebooks were reviewed by the prison authorities and twenty one of them bear their stamp. Thus, in the first place, it took some work to discern, for example, that "philosophy of praxis" meant Marxism; "Ilici" meant Lenin; "State-force" meant 'the dictatorship of the proletariat', and so on. ${ }^{40}$ As such, while one can certainly feel about for firm footing in this swamp of necessarily ambiguous language, it does also leave a fair deal of room for interpretation.

What is one to take from these differing understandings, then? Perhaps most important is that the idea of hegemony itself, in its basic form, is a concept that offers room for agreement between

\footnotetext{
${ }^{35}$ Glassman, 18.

${ }^{36}$ Glassman, 19.

${ }^{37}$ Genovese, From Rebellion, 134-135.

${ }^{38}$ Genovese, From Rebellion, 28-29.

${ }^{39}$ Genovese, From Rebellion, 102.

${ }^{40}$ Cammett, 189,
} 
scholars. We see several common formulations in all the writings on hegemony: "cultural knowledge", "class alliances", "power over ideology/discourse", and so on. The surrounding conceptual understandings that Gramsci fed into this concept are, to a larger degree, what make up the well-known fog that surrounds this idea. It is these ideas that feed into the concept of hegemony that seem to be the primary elements that foster disagreement between scholars. As Gramsci understood the limits of Marxism to be dismantled, its dimensions expanded, so perhaps one should understand Gramsci. These historians could take their formulations of Gramsci and admit them to be revisions and expansions, if they were to dismiss their affectation of objectivity as regards what we can know from his writings, and instead, err on the side of treating their writing as an interpretation and enrichment of these concepts. 


\section{Bibliography}

Cammett, John M. Antonio Gramsci and the Origins of Italian Communism. Stanford: Stanford University Press. 1967.

Genovese, Eugene D. From Rebellion to Revolution: Afro-American Slave Revolts in the Making of the Modern World. Baton Rouge: Louisiana State University. 1979.

--. Roll, Jordan, Roll: The World the Slaves Made. New York: Pantheon Books. 1974.

Glassman, Jonathon. Feasts and Riots: Revelry, Rebellion, and Popular Consciousness on the Swahili Coast, 1856 - 1888. Portsmouth: Heinemann. 2003.

Hall, Stuart. “Gramsci's Relevance for the Study of Race and Ethnicity”. Journal of Communication Inquiry 10: 5 (1986) pg. 5 - 27.

King, Richard H. "Marxism and the Slave South". American Quarterly 29: 1 (1977) pg. 117 131 